\title{
Molybdenum mixed with glyphosate and alone via foliar spray in no-tillage common bean grown on corn stover ${ }^{1}$
}

\author{
Gessimar Nunes Camelo ${ }^{2}$, Geraldo Antonio de Andrade Araújo 3 , Renildes Lucio Ferreira Fontes 4 , \\ Luiz Antonio dos Santos Dias ${ }^{5}$, José Eustáquio de Souza Carneiro ${ }^{6}$, \\ Jamir de Moraes de Lisboa Júnior ${ }^{7}$, José Damato Neto ${ }^{8}$
}

\begin{abstract}
The effect of molybdenum (Mo) on common bean grown in desiccated corn stover in a no-tillage system was evaluated under two application modes: Mo mixed with the desiccant glyphosate and Mo direct spray to the bean leaves. The treatments (four replicates) were assigned to a completely randomized block design in a split-plot arrangement with the application of $\operatorname{Mo}\left(0,100,200,400\right.$ and $\left.800 \mathrm{~g} \mathrm{ha}^{-1}\right)$ mixed with glyphosate in the main plots and Mo foliar spray ( 0 and $100 \mathrm{~g} \mathrm{ha}^{-1}$ ) in the sub-plots. The field experiments were carried out in 2009 and 2010 in the municipality of Coimbra, Minas Gerais State, with the common bean cultivar Ouro Vermelho. Mo mixed with glyphosate had neither an effect on common bean yield nor on the Mo and $\mathrm{N}$ contents in leaves, however it increased the Mo and $\mathrm{N}$ contents in seeds. Application of Mo via foliar spray increased Mo content in leaves and Mo and N contents in seeds. The reapplication of molybdenum with glyphosate for desiccation in subsequent crops caused a cumulative effect of Mo content in bean seeds.
\end{abstract}

Key words: Phaseolus vulgaris L., desiccation, molybdenum fertilization.

\section{RESUMO}

\section{Molibdênio aplicado com glifosato e isolado por via foliar em feijoeiro cultivado sobre palhada de milho no sistema de plantio direto}

O objetivo deste trabalho foi estudar o efeito da aplicação do molibdênio (Mo), em mistura com dessecante, em feijoeiro cultivado sobre palhada de milho (Zea mays), no sistema de plantio direto. Utilizou-se o delineamento em blocos casualizados, com quatro repetições, no esquema de parcelas subdivididas. Nas parcelas, foram aplicadas doses de $\mathrm{Mo}\left(0,100,200,400\right.$ e $\left.800 \mathrm{~g} \mathrm{ha}^{-1}\right)$, juntamente com herbicida dessecante (Glifosato) e, nas subparcelas, duas doses de Mo ( 0 e $100 \mathrm{~g} \mathrm{ha}^{-1}$ ), por via foliar. O trabalho foi realizado no município de Coimbra, MG, nos anos de 2009 e 2010, utilizando-se o cultivar Ouro Vermelho. A aplicação das doses do molibdênio, em operação de dessecação, com glifosato, em sistema de plantio direto, não influenciou a produtividade de grãos e o teor foliar de molibdênio e de nitrogênio nas plantas de feijão; porém, elevou os teores de molibdênio e de nitrogênio nos grãos do feijoeiro. Os

Received: 06/06/2012; Approved:08/08/2013.

${ }^{1}$ Part of Master's Dissertation of the first author, submitted to the Graduate Program in Plant Science of the Universidade Federal de Viçosa. Research funded by CNPq and FAPEMIG.

${ }^{2}$ Agronomist engineer, Master of Science. Departamento de Fitotecnia, Universidade Federal de Viçosa, Campus Viçosa, Avenida Peter Henry Rolfs, s/n, 36570-000, Viçosa, Minas Gerais, Brasil. gessimarcamelo@yahoo.com.br (corresponding author).

${ }^{3}$ Agronomist engineer, Doctor of Science. Departamento de Fitotecnia, Universidade Federal de Viçosa, Campus Viçosa, Avenida Peter Henry Rolfs, s/n, 36570-000, Viçosa, Minas Gerais, Brasil. garaujo@ufv.br

${ }^{4}$ Agronomist engineer, Ph.D. Departamento de Solos, Universidade Federal de Viçosa, Campus Viçosa, Avenida Peter Henry Rolfs, s/n, 36570-000, Viçosa, Minas Gerais, Brasil. renildes@ufv.br

${ }^{5}$ Agronomist engineer, Doctor of Science. Departamento de Fitotecnia, Universidade Federal de Viçosa, Campus Viçosa, Avenida Peter Henry Rolfs, s/n, 36570-000, Viçosa, Minas Gerais, Brasil. lasdias@ufv.br

${ }^{6}$ Agronomist engineer, Doctor of Science. Departamento de Fitotecnia, Universidade Federal de Viçosa, Campus Viçosa, Avenida Peter Henry Rolfs, s/n, 36570-000, Viçosa, Minas Gerais, Brasil. eustaquiocarneiro@yahoo.com.br

${ }^{7}$ Graduate in Agronomy. Universidade Federal de Viçosa, Campus Viçosa, Avenida Peter Henry Rolfs, s/n, 36570-000, Viçosa, Minas Gerais, Brasil. jamir.junior@ufv.br

${ }^{8}$ Agronomist engineer, Master of Science. Universidade Federal de Viçosa, Campus Viçosa, Avenida Peter Henry Rolfs, s/n, 36570-000, Viçosa, Minas Gerais, Brasil. josedamato@bol.com.br 
teores de molibdênio nas folhas, bem como os teores de molibdênio e de nitrogênio nos grãos do feijoeiro aumentaram com a aplicação do molibdênio, isolado, por via foliar. A reaplicação do molibdênio, em operação de dessecação com glifosato, na mesma área, em cultivos subsequentes, proporcionou efeito acumulativo no teor de molibdênio nos grãos de feijão.

Palavras-chave: Phaseolus vulgaris L., herbicida, adubação molíbdica.

\section{INTRODUCTION}

The increase in common bean (Phaseolus vulgaris L.) yield and therefore the decrease of the relative cost of micronutrient application, such as Mo, mainly because of its participation in symbiotic nitrogen fixation and nitrate reductase structure, as well as the expected gains in scale, have prompted research and application of this element in common bean fertilization (Berger et al., 1996; Pessoa et al., 2001; Ascoli et al., 2008).

Although common bean is capable of establishing symbiotic associations with rhizobia and fixing atmospheric nitrogen $\left(\mathrm{N}_{2}\right)$, the crop depends on supplemental nitrogen fertilizer to achieve substantial yields. In Brazil, the deficiency of nutrients in the soil, especially nitrogen $(\mathrm{N})$, is a major determinant of low bean yields. Because of the high cost of nitrogen fertilizers and the low purchasing power of most farmers, it is necessary to provide less costly alternatives, especially for lowincome farmers (Leite et al., 2007).

Nitrogen is the essential nutrient absorbed in the largest quantity by the bean crop and is required in amounts above $100 \mathrm{~kg} \mathrm{ha}^{-1}$ to ensure high yields (Fernandes et al., 2005). The application of foliar Mo is reported as effective in reducing the amount of nitrogen fertilizer to be used in the bean crop, since Mo is essential for the nitrogen metabolism in the plant. Mo participates as a structural element of the nitrogenase enzyme responsible for the symbiotic fixation of atmospheric nitrogen $\left(\mathrm{N}_{2}\right)$ to ammonia $\left(\mathrm{NH}_{3}\right)$ by Rhizobium, and also the nitrate reductase, the first step in the $\mathrm{N}$ incorporation into organic molecules (Marschner, 1995).

According to Wichard et al. (2009), the binding of Mo to organic matter helps stop leaching of the nutrient and is considered critical for fixing $\mathrm{N}$ in the ecosystems. In litter, Mo is strongly complexed with tannins derived from plants in a wide $\mathrm{pH}$ range and, in deeper soils, Mo binds both to iron oxides and organic matter (Wichard et al., 2009). These authors also suggested that organic-matter bound Mo can be captured by complexing agents released by $\mathrm{N}_{2}$-fixing bacteria.

No-tillage (NT) is a very important alternative in grain production that allows cultivation without major negative impacts on the environment and contributes to a greater conservation of soil and water resources. However, it is dependent on the quantity, quality and permanence of crop residue on soil surface, which is met by corn stover. The amount of crop residue provided by corn after export of grain has been enough to ensure efficient soil cover (Gomes Júnior et al., 2008), besides being a good rotation crop with legumes, such as common bean.

Although there is no response pattern to Mo, the increase in yield of the bean crop with supply of Mo has been reported in a number of studies in field conditions (Araújo et al., 2009; Nascimento et al., 2009; Biscaro et al., 2011; Rocha et al., 2011). Studies prove the feasibility of fertilizer foliar application on V4 stage bean, mainly of micronutrients tank-mixed with herbicides and pesticides to reduce costs and optimize equipment usage (Araújo et al., 2008; Silva et al., 2003b). In the experiment of 2008, Damato Neto (2010) found increased Mo content in bean seeds, but with no change in yield after application of Mo mixed with the desiccant glyphosate on corn stover in no-till.

There is evidence that the common bean is capable of absorbing the Mo applied to corn stover and mixed with desiccant, but there is no information about the crop performance over the years. Thus, the 2008 experiment of Damato Neto (2010) was repeated for two more years, in 2009 and 2010, to study the effect of different Mo rates applied in the desiccation with glyphosate on corn stover and alone via foliar spray in no-till bean.

\section{MATERIAL AND METHODS}

The two experiments conducted in 2009 and 2010 were carried out in the experimental station of the Department of Plant Science of the Universidade Federal de Viçosa located in the municipality of Coimbra, Minas Gerais. The geographic coordinates of the area are $20^{\circ} 50^{\prime} 30^{\prime \prime} \mathrm{S}$ and $42^{\circ} 48^{\prime} 30^{\prime \prime}$ O, $715 \mathrm{~m}$ altitude, in a dystrophic Red Yellow Podzolic soil of clay texture, with 540,180 and $280 \mathrm{~g} \mathrm{~kg}^{-1}$ of clay, silt and sand respectively (Embrapa, 2006) .

For cultivation of no-tillage common bean on corn (Zea mays) stover in second and third years, the corn crop was planted in November 2008 and 2009, respectively. The first experiment was established by sowing corn in December 2007 and sowing bean in May 2008 (Damato Neto, 2010). 
The subsequent experiments with bean were installed in the same field and the treatments were randomly assigned to plots. Before applying the treatments to the first bean crop (2008), soil samples were collected at a depth of 0-20 $\mathrm{cm}$ for the chemical analysis (Table 1). Common bean cultivar Red Gold (indeterminate growth, plant type II/II) was sown (15 seeds $\left.\mathrm{m}^{-1}\right)$ in March 26, 2009 and April 14, 2010 (autumn-winter planting), using a seeder-fertilizer machine with double disc furrow opener with offset discs.

The treatments (four replicates) were assigned to a completely randomized block design in a split-plot arrangement with the application of $\mathrm{Mo}(0,100,200,400$ and $800 \mathrm{~g} \mathrm{ha}^{-1}$ ) mixed with glyphosate (isopropylamine salt - Roundup Original ${ }^{\circledR}-1440$ g e.a. ha $\left.{ }^{-1}\right)$ in the main plots and Mo foliar spray ( 0 and $100 \mathrm{~g} \mathrm{ha}^{-1}$ ) in the sub-plots.

The plots consisted of four rows of bean plants $(10 \mathrm{~m}$ long and $0.5 \mathrm{~m}$ apart) divided into subplots of $5 \mathrm{~m}$ long rows. The harvest area of the subplot was delimited by the two central rows $\left(4 \mathrm{~m}^{2}\right)$, excluding $0.5 \mathrm{~m}$ on each end of the rows.

In both years, 13 days before sowing, desiccation of weeds along the corn stover was done with glyphosate mixed with $\mathrm{Mo}$ (sodium molybdate - $\mathrm{Na}_{2} \mathrm{MoO}_{4}$ - with $39 \%$ Mo) using the rates mentioned above. The application was performed using a $\mathrm{CO}_{2}$-pressurized backpack sprayer (2 bar), equipped with a 2-m spray bar, TT 11002 flat fan nozzles spaced $50 \mathrm{~cm}$ which delivered a spray volume of $140 \mathrm{~L} \mathrm{ha}^{-1}$.

The starter fertilizer was placed in furrow, using $350 \mathrm{~kg}$ $\mathrm{ha}^{-1}$ of the 8-28-16 $\left(\mathrm{N}-\mathrm{P}_{2} \mathrm{O}_{5}-\mathrm{K}_{2} \mathrm{O}\right)$ formulation. Foliar fertilization $\left(\mathrm{Na}_{2} \mathrm{MoO}_{4}\right.$ with $\left.39 \% \mathrm{Mo}\right)$ was sprayed on V4stage bean plants, using a backpack sprayer with pressure relief valve ( 2 bar) (VPC azul-465344; Jacto) equipped with a 2-m spray bar, TT 11002 flat fan nozzles spaced $50 \mathrm{~cm}$ which delivered a spray volume of $180 \mathrm{~L} \mathrm{ha}^{-1}$.

In both experiments, the nitrogen fertilization was carried out 28 days after seedling emergence (DAE) by hand application of $45 \mathrm{~kg} \mathrm{ha}^{-1}$ of $\mathrm{N}$ as urea, next to the row on the soil surface. After $\mathrm{N}$ application, irrigation was applied (under $10 \mathrm{~mm}$ of water layer) to minimize losses by volatilization.

Weed control in the bean crop was carried out with a commercial mixture of herbicides fluazifop-p-butyl + fomesafen $\left(200+250 \mathrm{~g} \mathrm{~L}^{-1}\right.$, respectively $)$ at the commercial rate of $0.8 \mathrm{~L} \mathrm{ha}^{-1}$, in both years. If necessary, plants were sprayed with the fungicide azoxystrobin (120 $\left.\mathrm{g} \mathrm{ha}^{-1}\right)$ to control rust [Uromyces appendiculatus (Pers.) Unger] and angular leaf spot [Phaeoisariopsis griseola (Sacc.) Ferraris] and Fluazinan for white mold (Sclerotinia sclerotiorum). Insect control with deltamethrin ( $\left.80 \mathrm{ml} \mathrm{ha}^{-1}\right)$ was applied when the pest population was moderate. The crop was kept under sprinkler irrigation. The soil water content was maintained near field capacity.

SPAD index readings (Soil Plant Analyses Development) were measured using a Minolta SPad502 chlorophyll meter on third fully expanded trifoliate leaves, from the apex, in ten R5-stage plants randomly selected within the harvest area of the subplot, always between 9:00 and 10:00 am. The average of the readings of the ten sampled plants represented the value of the subplot. These leaves were also used for analyses of $\mathrm{N}$ and Mo.

After the physiological maturity stage, plants were harvested from the subplot and left in the sun to finish drying. The following variables were determined: final stand (plants ha-1), pod number per plant, seed number per pod, 100 -seed mass and seed yield. Seed yield $\left(\mathrm{kg} \mathrm{ha}^{-1}\right)$ was calculated from the production of the harvest area of each subplot, standardizing the moisture content (wet basis) at $13 \%$. Seed samples were also collected from the harvest area of each subplot.

Leaf and seed samples of bean were ground and mixed for nitropercloric digestion and Mo was determined by inductively coupled plasma optical emission spectrometry using a Perkin Elmer Optima 3300 DV simultaneous spectrometer. Leaf nitrogen content was calculated by summing the organic-N contents determined (after sulfuric acid digestion) by the Nessler's reagent colorimetric method and the nitrate-N contents (Malavolta et al., 1997). Seed nitrogen content was determined by the micro-Kjeldahl method (Malavolta et al., 1997).

For statistical analysis we used individual and combined analysis of variance, with the SAS Institute 9.1 for Windows (SAS, 2003). Means of the treatments with and without Mo application were compared by the F test. The models for the quantitative factors (rate of Mo mixed with glyphosate) were chosen based on the significance of the coefficients of regression ( $t$ test at $5 \%$ probability) and determination $\left(\mathrm{R}^{2}=\mathrm{SS}\right.$ Regression/SS Treatment $)$, as well as the inherent characteristics of the biological phenomenon under study.

Table 1. Soil chemical characteristics* at $0-20 \mathrm{~cm}$ depth in the experimental area, Coimbra - MG

\begin{tabular}{|c|c|c|c|c|c|c|c|c|c|c|c|c|}
\hline pH & $\mathbf{P}$ & $\mathbf{K}^{+}$ & $\mathbf{H}+\mathbf{A l}$ & $\mathrm{Al}^{3+}$ & $\mathrm{Ca}^{2+}$ & $\mathrm{Mg}^{2+}$ & CTC $_{\text {total }}$ & CTC $_{\text {effective }}$ & SB & $\mathbf{V}$ & M & P-rem \\
\hline $\mathrm{H}_{2} \mathrm{O}$ & $\mathrm{mg} \mathrm{dm}^{-3}$ & \multicolumn{8}{|c|}{$\mathrm{cmol}_{\mathrm{c}} \mathrm{dm}^{-3}$} & \multicolumn{2}{|c|}{$\%$} & $\mathrm{mg} \mathrm{L}^{-1}$ \\
\hline 6.1 & 7.4 & 95 & 3.8 & 0.0 & 2.7 & 1.1 & 7.8 & 4.0 & 4.0 & 52 & 0.0 & 24.5 \\
\hline
\end{tabular}

Rev. Ceres, Viçosa, v. 61, n.1, p. 062-069, jan/fev, 2014 


\section{RESULTS AND DISCUSSION}

There was no effect of Mo rates mixed with glyphosate applied for desiccation on the final stand of beans grown on corn stover. However, in the evaluation of the interaction of Mo rate applied by foliar spray and the year, with or without Mo application, the number of plants per hectare in the final stand in 2009 was higher than in 2010 (Table 2). It is noteworthy that in 2009, with the foliar application of Mo, the final stand had higher number of plants per hectare than those not fertilized with Mo (Table 2).

There was no effect of Mo rates mixed with glyphosate on pod number per plant (PNP) (mean $=10.24$ un.; Standard deviation $=0.92$ un.). This result was similar to that reported by Barbosa et al. (2010) with different $\mathrm{N}$ rates, in the presence or absence of $80 \mathrm{~g} \mathrm{ha}^{-1} \mathrm{Mo}$, finding no significant influence on PNP in two years of winter bean cultivation. Fernandes et al. (2005) evaluated the application of foliar Mo and N, in-furrow or sidedress, to no-tillage bean on corn stover and also found no difference for PNP. However, reports of increased PNP in response to Mo application are common in the literature (Pessoa et al., 2001; Silva et al., 2003a; Nascimento et al., 2009). For the year effect, the average PNP was higher in 2010 (Table 3 ). The probable reason for this fact is the plasticity of bean plants, which are able to compensate the primary yield components in different environmental conditions, including the plant population (Piana et al., 2007), which in 2010 was lower than in 2009 (Table 2).

Rates of Mo mixed with glyphosate applied for desiccation and rates of Mo applied by foliar spray did not influence the seed number per pod $(\mathrm{SNP})($ mean $=6.12$ un.; standard deviation $=0.35$ un.) and the 100 -seed mass $(100 \mathrm{SM})($ mean $=25.64 \mathrm{~g}$; standard deviation $=0.66 \mathrm{~g})$. However, there was significant difference in the SNP between the years of cultivation; in 2009, the average was lower than in 2010 (Table 3), which was similar to result reported by Ascoli et al., (2008). Nevertheless, Leite et al., (2007) observed increase in these yield components (SNP; 100SM) with the application of foliar Mo to common bean.

Mo rates mixed with glyphosate had no significant effect on SPAD readings; means ranged from 39.5 to 41.2 SPAD un.. These results were different from those found by Pires et al. (2004) and Ferreira et al. (2002), who found increase in SPAD index of 29 and 37\%, respectively, for common bean fertilized with molybdenum. However, we found difference in the SPAD index reading between the two years. In 2009, the average was higher than in 2010 (Table 3). Ferreira et al. (2002) also found variation in SPAD index readings from one year to another, using the same cultivar.

Seed yield (SY) was not influenced by the combination of different rates of Mo with glyphosate (mean $=2772.2$ $\mathrm{kg} \mathrm{ha}^{-1} ; \mathrm{SD}=200.7 \mathrm{~kg} \mathrm{ha}^{-1}$ ). The coefficients of variation $(\mathrm{CV} \%)$ in the plot and subplot were respectively, 12.7 and 7.2. These CV values are below acceptable limits for the common bean (Oliveira et al., 2009). It is important to note that the experiment had an adequate degree of precision, reflected in the low $\mathrm{CV}$ values reported for the other yield components (Table 3 ).

The lack of yield response may be related to the concentration of the nutrient in the soil-plant system. The soil $\mathrm{pH}(6.1)$ in the area where the experiments were installed (Table 1) may have contributed to the increased availability of Mo, providing the adequate amount for the

Table 2. Unfolding of the significant interactions in the analysis of variance for final stand and leaf Mo content (LMoC) of common bean grown on corn stover, in 2009 and 2010, Coimbra - MG

\begin{tabular}{|c|c|c|c|c|}
\hline \multirow{2}{*}{ Mo Foliar } & \multicolumn{2}{|c|}{ Final stand } & \multicolumn{2}{|c|}{ LMoC } \\
\hline & 2009 & 2010 & 2009 & 2010 \\
\hline $\mathrm{g} \mathrm{ha}^{-1}$ & \multicolumn{2}{|c|}{ plants ha ${ }^{-1}$} & \multicolumn{2}{|c|}{$\mathrm{mg} \mathrm{kg}^{-1}$} \\
\hline 0 & $178625 \mathrm{Ab}$ & $166000 \mathrm{Ba}$ & $0.41 \mathrm{Ab}$ & $0.43 \mathrm{Ab}$ \\
\hline 100 & $193000 \mathrm{Aa}$ & $164750 \mathrm{Ba}$ & $1.87 \mathrm{Ba}$ & $3.67 \mathrm{Aa}$ \\
\hline
\end{tabular}

Means followed by the same capital in the row and small letter in the column are not significantly different by the $\mathrm{F}$ test at $5 \%$ probability.

Table 3. Pod number per plant (PNP), seed number per pod (SNP) and SPAD Reading (SPAD) of no-till common bean grown on corn stover, in 2009 and 2010, Coimbra - MG

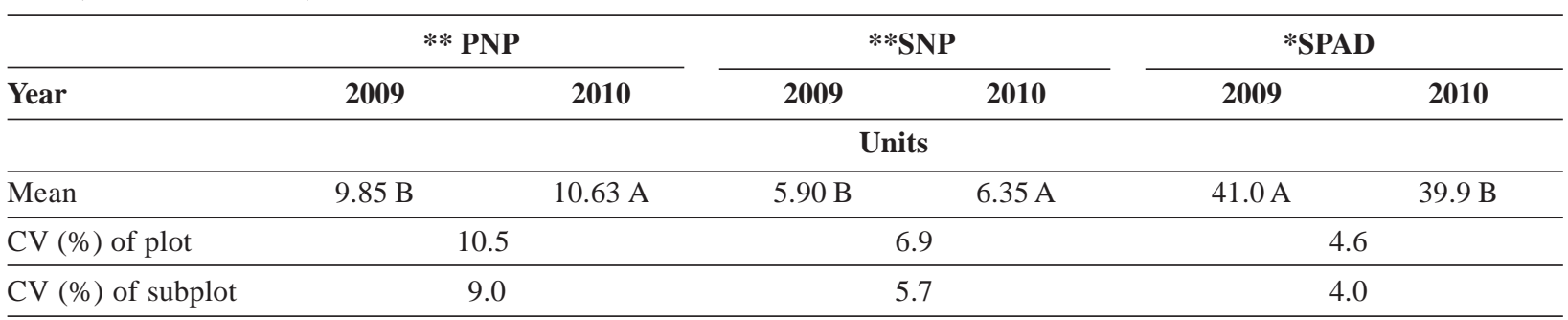

Means followed by the same capital letter in the row are not significantly different by the $\mathrm{F}$ test; at $* 5 \%$ probability and ** $\mathrm{F} 1 \%$ probability levels 
plant to complete its life cycle. In soils with relatively high $\mathrm{pH}$ (greater than 6.0), response to the application of Mo is not usually expected, because there is increased availability of the micronutrient with increasing $\mathrm{pH}$ (Silva et al., 2012). Another reason for the lack of difference between yield means is that the application of $45 \mathrm{~kg} \mathrm{ha}^{-1}$ sidedress $\mathrm{N}$ in the form of urea and the amount of $\mathrm{N}$ released by microbial mineralization of organic matter have supplied bean plants.

Calonego et al. (2010) evaluated the effect of five $\mathrm{N}$ rates $\left(25,50,75,100\right.$ and $\left.125 \mathrm{~kg} \mathrm{ha}^{-1}\right)$ applied 20 days after emergence (DAE) associated with and without foliar application of $80 \mathrm{~g} \mathrm{ha}^{-1} \mathrm{Mo}$ at $25 \mathrm{DAE}$ and found that the molybdenum fertilization increased bean yield regardless of sidress $\mathrm{N}$ rates. In a similar study, Biscaro et al. (2011) found that sidedress $\mathrm{N}$ increased the seed yield of common bean only when combined with foliar Mo.

Leaf molybdenum content ( $\mathrm{LMoC}$ ) was not influenced by the rates of Mo mixed with glyphosate, with means (two years) ranging from 1.26 to $2.09 \mathrm{mg} \mathrm{kg}^{-1}$. However, these means showed a trend of linear increase with increasing rates of Mo mixed with glyphosate. Failure to statistically detect differences among the LMoC means, as a function of Mo rates mixed with glyphosate, was probably due to the high CV\% of the data (Table 4). Other studies reported increased $\mathrm{LMoC}$ in beans with Mo supplementation (Ferreira et al., 2003; Pires et al., 2005). When comparing the years, LMoC was higher in 2010 (Table 4).

Foliar application of Mo influenced LMoC. The average LMoC of treatments that received Mo supplementation ( $\left.100 \mathrm{~g} \mathrm{ha}^{-1}\right)$ was $2.77 \mathrm{mg} \mathrm{kg}^{-1}$, while the average $\mathrm{LMoC}$ of treatments without additional Mo was $0.42 \mathrm{mg} \mathrm{kg}^{-1}$. In the interaction Mo foliar spray and year, regardless of the year, the lowest means of LMoC occurred in subplots without foliar application of Mo (Table 2). The subplots with foliar application of Mo had LMoC means higher in 2010 (Table 2). It stands out that, in both years, the $\mathrm{LMoC}$ means recorded in plots without foliar Mo were within the sufficiency range for LMoC (0.40 to $\left.1.40 \mathrm{mg} \mathrm{kg}^{-1}\right)$ proposed for the common bean by Oliveira \& Thung (1988). That is, the lack of
Mo fertilization was not limiting for the development of the legume.

There was no effect of application of Mo rates mixed with glyphosate on leaf $\mathrm{N}$ content (LNC) of no-till beans grown on corn stover. Means ranged from 5.04 to 5.34 dag $\mathrm{kg}^{-1}$. The LNC found in this study are greater than those reported by Martinez et al. (1999) as the sufficiency range of $\mathrm{N}$ for the common bean ( 3.0 to $3.5 \mathrm{dag} \mathrm{kg}^{-1}$ ).

Seed Mo content (SMoC), in the interaction of Mo rates mixed with glyphosate x year (Figure 1), increased with the rate of Mo mixed with the desiccant applied on corn stover, regardless of the year. However, seeds harvested in 2010 had higher average SMoC, which shows the ability of bean plants to absorb and accumulate Mo in the seeds, even when applied with glyphosate at the time of desiccation. This ability, according to Jacob Neto \& Rossetto (1998), is an advantage for seed production, since seed reserves of molybdenum are usually sufficient for the plant to grow without depending on Mo supplementation. There is evidence that Mo content exceeding $1.272 \mu \mathrm{g}$ per seed would benefit plants with regard to leaf $\mathrm{N}$ content and yield (Vieira et al. 2005).

The application of Mo alone, by foliar spray, increased SMoC. In the treatments without foliar application of Mo, the average $\mathrm{SMoC}$ was $1.75 \mathrm{mg} \mathrm{kg}^{-1}$, while in the subplot with additional application of $100 \mathrm{~g} \mathrm{ha}^{-1} \mathrm{Mo}$, the average $\mathrm{SMoC}$ was $4.27 \mathrm{mg} \mathrm{kg}^{-1}$. For the year effect, similar to what happened to LMoC, the SMoC in 2010 was higher than the average of 2009 (Table 4).

There was no effect of application of Mo rates mixed with glyphosate on seed nitrogen content (SNC). Means were not significantly different $(\mathrm{p}<0.05)$, but the data did not fit the regression models. The plots without application of Mo mixed with glyphosate had average SNC of 3.62 dag $\mathrm{kg}^{-1}$, or $5 \%$ lower than the average (3.80 dag $\mathrm{kg}^{-1}$ ) of those applied with Mo mixed with glyphosate (Table 5). For the year effect, in 2009 the average SNC was lower than the average of 2010. This result may be due to the use of Mo accumulated in the soil, from applications in the previous years (Table 4). The practical application of this information is that it is possible to reduce the use of Mo mixed with the desiccant over the years.

Table 4. Leaf molybdenum content (LMC), seed molybdenum content (SMoC) and seed nitrogen content (SNC) in no-till common bean grown on corn stover, in 2009 and 2010, Coimbra - MG

\begin{tabular}{|c|c|c|c|c|c|c|}
\hline \multirow[b]{2}{*}{ Year } & \multicolumn{2}{|c|}{ LMoC } & \multicolumn{2}{|c|}{ SMoC } & \multicolumn{2}{|c|}{ SNC } \\
\hline & 2009 & 2010 & 2009 & 2010 & 2009 & 2010 \\
\hline & \multicolumn{4}{|c|}{$\mathrm{kg}^{-1}$} & \multicolumn{2}{|c|}{ dag $k^{-1}$} \\
\hline Mean & $1.14 \mathrm{~B}$ & $2.05 \mathrm{~A}$ & $2.72 \mathrm{~B}$ & $3.30 \mathrm{~A}$ & $3.51 \mathrm{~B}$ & $4.03 \mathrm{~A}$ \\
\hline $\mathrm{CV}(\%)$ of plot & \multicolumn{2}{|c|}{88.7} & \multicolumn{2}{|c|}{22.5} & \multicolumn{2}{|c|}{4.8} \\
\hline CV (\%) of subplot & \multicolumn{2}{|c|}{86.2} & \multicolumn{2}{|c|}{18.1} & \multicolumn{2}{|c|}{3.5} \\
\hline
\end{tabular}

Means followed by the same capital letter in the row are not significantly different by the $\mathrm{F}$ test; at $1 \%$ probability level. 
Seed $\mathrm{N}$ content (SNC), in the interaction of Mo rates mixed with glyphosate $\mathrm{x}$ Mo foliar spray (Figure 2), remained constant when $100 \mathrm{~g} \mathrm{ha}^{-1}$ of Mo were applied on bean leaves. However, without foliar Mo, there was an exponential response of SNC means that required a rate of $199 \mathrm{~g} \mathrm{ha}^{-1}$ Mo mixed with glyphosate to equal the average $\mathrm{N}$ content obtained with the foliar application of Mo (Figure 2). These results showed that bean plants absorbed and translocated the Mo applied with glyphosate to the seeds, making it unnecessary its application via foliar spray under these conditions.

There was significant effect of Mo application to common bean plants via foliar spray on SNC. The subplots without application of Mo via foliar spray had average SNC equal to $3.72 \mathrm{dag} \mathrm{kg}^{-1}$, which was lower than the average of the subplots with the additional application of $100 \mathrm{~g} \mathrm{ha}^{-1} \mathrm{Mo}, 3.81 \mathrm{dag} \mathrm{kg}^{-1}$.

Table 5. Means for seed N content (SNC) of no-till common bean grown on corn stover as a function of Mo rates mixed with glyphosate in 2009 and 2010 , Coimbra MG

\begin{tabular}{|c|c|c|c|c|c|c|}
\hline \multirow[b]{2}{*}{ Mo g ha $^{-1}$} & \multicolumn{5}{|c|}{1.440 g e.a. ha ${ }^{-1}$ Glyphosate + Mo rate } & \multirow{2}{*}{ Mean } \\
\hline & $\mathbf{0}$ & 100 & 200 & 400 & 800 & \\
\hline $\mathrm{SNC}\left(\right.$ dag kg $\left.^{-1}\right)$ & 3.62 & 3.82 & 3.73 & 3.84 & 3.82 & 3.77 \\
\hline
\end{tabular}

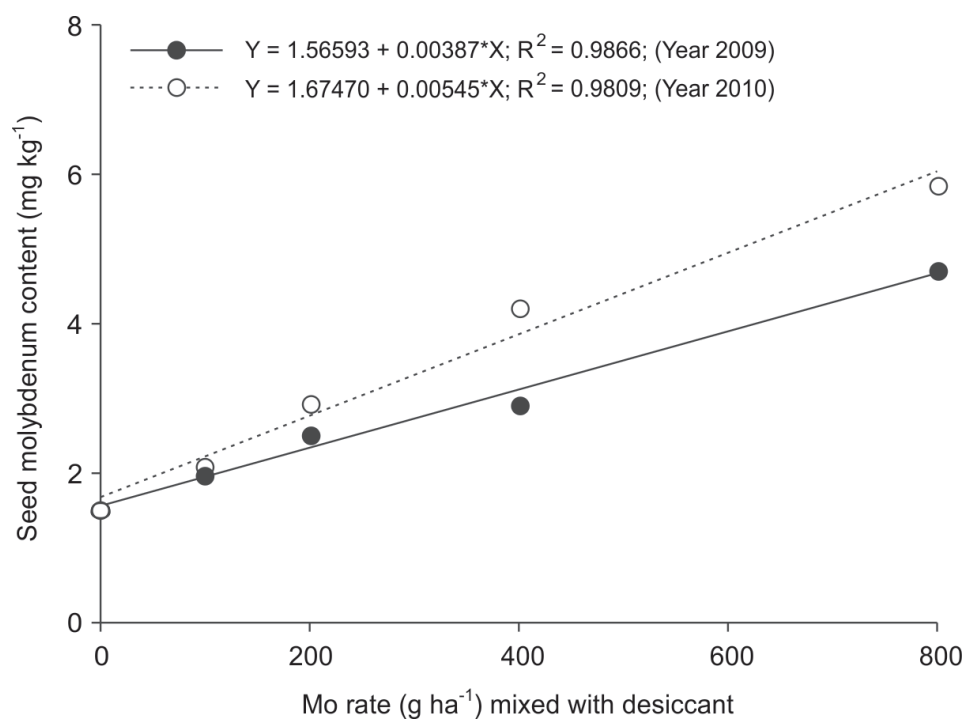

Figure 1. Seed Mo content of common bean as a function of Mo rates mixed with glyphosate in 2009 and 2010, Coimbra - MG .

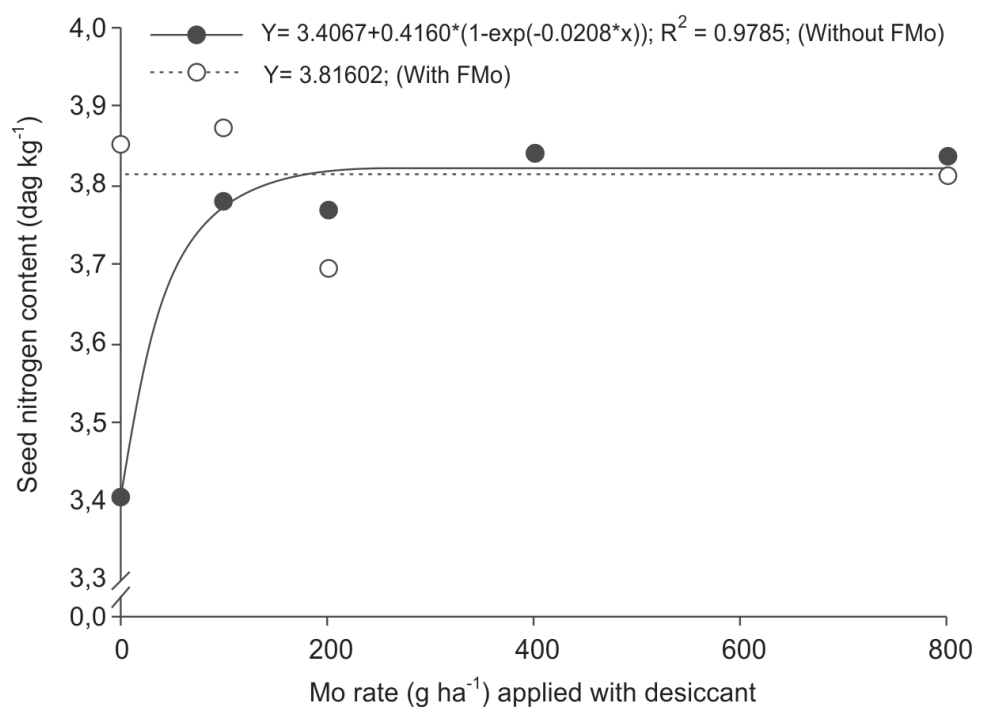

Figure 2. Seed N content of common bean, with or without foliar Mo application as a function of Mo rates mixed with glyphosate, Coimbra - MG 


\section{CONCLUSIONS}

The application of molybdenum rates mixed with glyphosate for desiccation in no-tillage system did not affect seed yield and leaf content of molybdenum and nitrogen in bean plants, but increased the contents of molybdenum and nitrogen in the seeds. The molybdenum content in leaves as well as the molybdenum and nitrogen contents in bean seeds increased with the application of molybdenum via foliar spray. The re-application of molybdenum mixed with glyphosate for desiccation in subsequent crops caused a cumulative effect of molybdenum content in common bean seeds.

\section{AKNOWLEGEMENT}

The authors want to thank the National Council for Scientific and Technological Development - CNPq and the Foundation of Research of Minas Gerais - FAPEMIG, for granting the scholarship and the financial support to this research.

\section{REFERENCES}

Araújo GAA, Silva AA, Thomas A \& Rocha PRR (2008) Misturas de herbicidas com adubo molíbdico na cultura do Feijão. Planta Daninha, 26:237-247.

Araújo PRA, Araújo GAA, Rocha PRR \& Carneiro JES (2009) Combinações de doses de molibdênio e nitrogênio na adubação da cultura do feijoeiro-comum. Acta Scientiarum Agronomy, $31: 227-234$.

Ascoli AA, Soratto RP \& Maruyama WI (2008) Aplicação foliar de molibdênio, produtividade e qualidade fisiológica de sementes de feijoeiro irrigado. Bragantia, 67:377-384.

Barbosa GF, Arf O, Nascimento MS, Buzetti S \& Freddi OS (2010) Nitrogênio em cobertura e molibdênio foliar no feijoeiro de inverno. Acta Scientiarum Agronomy, 32:117-123.

Berger PG, Vieira C \& Araújo GAA (1996) Efeitos de doses e épocas de aplicação do Molibdênio sobre a cultura do feijão. Pesquisa Agropecuária Brasileira, 31:473-480.

Biscaro GA, Freitas Junior NA, Soratto RP, Kikuti H, Goulart Junior SAR \& Aguirre WM (2011) Nitrogênio em cobertura e molibdênio via foliar no feijoeiro irrigado cultivado em solo de cerrado. Acta Scientiarum Agronomy, 33:665-670.

Calonego JC, Ramos Junior EU, Barbosa RD, Leite GHP \& Grassi Filho H (2010) Adubação nitrogenada em cobertura no feijoeiro com suplementação de molibdênio via foliar. Revista Ciência Agronômica, 41:334-340.

Damato Neto J (2010) Resposta do feijoeiro ao molibdênio em mistura com glyphosate no plantio direto. Dissertação de Mestrado. Universidade Federal de Viçosa, Viçosa. 46p.

Embrapa - Empresa Brasileira de Pesquisa Agropecuária (2006) Sistema Brasileiro de Classificação de Solos. $2^{\mathrm{a}}$ ed. Rio de Janeiro, Embrapa Solos. 412p.

Fernandes FA, Arf O, Binotti FFS, Romanini Junior A, Sá ME, Buzetti S \& Rodrigues RAF (2005) Molibdênio foliar e nitrogênio em feijoeiro cultivado no sistema plantio direto. Acta Scientiarum Agronomy, 27:07-15.
Ferreira ACB, Araújo GAA, Cardoso AA, Fontes PCR \& Vieira C (2002) Influência do molibdênio contido na semente e da sua aplicação foliar sobre a composição mineral de folhas e sementes do feijoeiro. Revista Ceres, 49:443-452.

Ferreira ACB, Araújo GAA, Cardoso AA, Fontes PCR \& Vieira C (2003) Diagnose do estado nutricional molíbdico do feijoeiro em razão do molibdênio contido na semente e sua aplicação foliar. Revista Brasileira de Agrociência, 9:397-401.

Gomes Junior FG, Sá ME \& Valério Filho WV (2008) Nitrogênio no feijoeiro em sistema de plantio direto sobre gramíneas. Acta Scientiarum Agronomy, 30:387-395.

Jacob Neto J \& Rosseto CAV (1998) Concentração de nutrientes nas sementes: o papel do molibdênio. Floresta e Ambiente, 5:171183.

Leite UT, Araújo GAA, Miranda GV, Vieira RF, Carneiro JES \& Pires AA (2007) Rendimento de grãos e componentes de rendimento do feijoeiro em função da aplicação foliar de doses crescentes de molibdênio. Acta Scientiarum Agronomy, 29:113120 .

Malavolta EA, Vitti GC \& Oliveira AS (1997) Avaliação do estado nutricional das plantas: princípios e aplicações. Piracicaba, Potafós. 201p.

Marschner H (1995) Mineral nutrition of higher plants. San Diego, Academic Press. 889p.

Martinez HEP, Carvalho JG \& Souza RB (1999) Diagnose foliar. In: Ribeiro AC, Guimarães PTG \& Alvarez V VH (Eds.) Recomendações para o uso de corretivo e fertilizante em Minas Gerais: 5a Aproximação. Viçosa, Comissão de Fertilidade do Solo do Estado de Minas Gerais. p.143-168

Nascimento MS, Arf O, Barbosa GF, Buzetti S, Nascimento RS \& Castro RM (2009) Nitrogênio em cobertura e molibdênio via foliar em feijoeiro de inverno no sistema plantio direto II características agronômicas e produtividade. Scientia Agrária, 10:351-358

Oliveira IP \& Thung MDT (1988) Nutrição mineral. In: Zimmermann MJO, Rocha M \& Yamada T (Eds.) Cultura do feijoeiro: fatores que afetam a produtividade. Piracicaba, Potafós. p. 175-212.

Oliveira RL, Muniz JA, Andrade MJB \& Reis RL (2009) Precisão experimental em ensaios com a cultura do feijão. Ciência e Agrotecnologia, 33:113-119.

Pessoa ACS, Ribeiro AC, Chagas JM \& Cassini STA (2001) Atividades de nitrogenase e redutase de nitrato e produtividade do feijoeiro "Ouro Negro" em resposta à adubação foliar com molibdênio. Revista Brasileira de Ciência do Solo, 25:217-224.

Piana CFB, Silva JGC \& Antunes IF (2007) Ajuste do rendimento para variação do estande em experimentos de melhoramento genético do feijão. Pesquisa Agropecuária Brasileira, 42:16871696.

Pires AA, Araújo GAA, Miranda GV, Berger PG, Ferreira ACB, Zampirolli PD \& Leite UT (2004) Rendimento de grãos, componentes do rendimento e Índice SPAD do feijoeiro (Phaseolus vulgaris L.) em função de época de aplicação e do parcelamento da aplicação foliar de molibdênio. Ciência e Agrotecnologia, 28:1092-1098.

Pires AA, Araújo GAA, Leite UT, Zampirolli PD, Ribeiro JMO \& Meireles RC (2005) Parcelamento e época de aplicação foliar do molibdênio na composição mineral das folhas do feijoeiro. Acta Scientiarum Agronomy, 27:25-31.

Rocha PRR, Araújo GAA, Carneiro JES, Cecon PR \& Lima TC (2011) Adubação molíbdica na cultura do feijão nos sistemas de plantio direto e convencional. Revista Caatinga, 24:09-17. 
SAS Institute Inc. (2003) SAS system for windows. Version 9.1 Cary, Statistical Analysis System Institute. CD-ROM.

Silva EB, Santos SR, Fonseca FG, Tanure LPP \& Freitas JPX (2012) Aplicação foliar de molibdênio em feijoeiro irrigado cultivado no norte de Minas Gerais. Bioscience Journal, 28:64-71.

Silva MV, Andrade MJB, Moraes AR \& Alves VG (2003a) Fontes e doses de molibdênio via foliar em duas cultivares de feijoeiro. Ciência e Agrotecnologia, 27:126-133.

Silva MV, Andrade MJB, Ramalho MAP \& Alves VG (2003b) Aplicação foliar simultânea de molibdênio e alguns defensivos agrícolas na cultura do feijoeiro. Ciência e Agrotecnologia, 27:1160-1164
Vieira RF, Salgado LT \& Ferreira ACB (2005) Performance of common bean using seeds harvested from plants fertilized with high rates of molybdenum. Journal of Plant Nutrition, 28:363377.

Wichard T, Mishra B, Myneni SC, Bellenger JP \& Kraepiel AML (2009) Storage and bioavailability of molybdenum in soils increased by organic matter complexation. Nature Geoscience, 2:625-629. 